UDC 656.078.1

JEL Classification M 21

DOI 10.31375/2226-1915-2018-4-14-25
Matviienko M.

Ph.D., associate Professor

of the Enterprenership and Tourism Department marinimus029@gmail.com

Odessa National Maritime University. Odessa, Ukraine

\title{
BUSINESS STRUCTURES AT A MARITIME ENTERPRISE
}

\begin{abstract}
Research presented in this paper aims to develop a methodology to depict organizational structures of transport and to depict organizational structures with some methodology. The goal is to make it possible to compare different organizational structures of maritime transport services diagrammatically and to analyze the role of the organizational structure in association with usability of maritime transport. With various business modeling methodologies reviewed, the methodology used in this paper is based on UML (Unified Modeling Language). Unified Modeling Language is originally developed for object-oriented software engineering. Most important and relevant diagrams can be selected so that the aspects that are to be modeled are rationally presented because it is time- and resource consuming. The most basic diagram - class diagram can present static structures, and the most basic one to present dynamic process is activity diagram. It is useful because this provides a powerful analytical method to create diagrams from various data and information sources. With data and information collected from literature, as a first attempt, generic diagrams are created to present developments of maritime transport organizations from one representing fairly simple transport enterprises to another representing typical modern transport undertaking. Several diagrams are created to represent various complex organizational structures of transport with a focus set on users' points of view. The method based on UML enables simple and easy-to-understand diagrammatic comparison of various organizational structures with a large extent of flexibility. It enables successful presentation of evolution of the organizational structure. The user-focused presentations and a comparison of them highlights that the organizational structure, especially whether there is a system integrator from users' points of view, does have a strong influence on usability. Especially important is the reasonable construction of the structure for the enterprises of maritime transport. This is due to the fact that the competition in the industry is very high. Structure errors are costly for owners and lead to the need to exit the market.

The user-oriented structure shows that the service structure from users' points of view can be useful tool for management, communication, planning and rebuilding transport company on different stages of development. Proposed methodology makes it possible to present various organizational structure with a big extent of flexibility. This means that various ways of presentation based on different focuses is made possible. This can serve also as a strong communication tool among various stakeholders. Proposed method can also be applied to different occasions, such as integration.
\end{abstract}

\footnotetext{
(C) Matviienko M., 2018
} 
With users' viewpoints embedded in the diagrams, relationships between different levels of usability and differrent organizational structures, especially the existence of system integrators, are visually depicted. This methodology can be used to improve user experiences of marine transport through organizational approach.

Keywords: methodology, organizational structure, business structure, maritime transport, usability.

УДК 656.078.1

JEL Classification M 21

DOI 10.31375/2226-1915-2018-4-14-16
М. Матвіснко

к.е.н., доцент кафедри «Підприємництво і туризм»

Одеський національний морський університет, Одеса, Украӥна

\section{БІЗНЕС-СТРУКТУРИ ДЛЯ ПІДПРИЄМСТВА МОРСЬКОГО ТРАНСПОРТУ}

Аннотація. Дослідження, представлені в ціий статті, спрямовані на розробку методології побудови організаційних структур підприємств морського транспорту та виявлення організаційних структур за допомогою певної методологіï. Мета полягає в тому, щоб зробити схематичне порівняння різних організаційних структур морських транспортних послуг та проаналізувати роль організаиійної структури у зв'язку з зручністю використання морського транспорту. 3 огляду на різні методології бізнес-моделювання, методологія, використана в даному документі, базується на UML (Unified Modeling Language), оскільки це потужний аналітичний метод для створення діаграм з різних джерел даних та інформаиії. 3 даних та інформащії, зібраної з літератури, як перма спроба, створюються загальні діаграми, що дозволяють відобразити еволюцію бізнес-структури морських транспортних організаиій від однієї з досить простих форм до іншої, що представляє типове сучасне транспортне підприсмство. Створено декілька діаграм для представлення різних складних організаційних структур транспорту з фокусом, встановленим з точки зору користувачів. Метод, заснований на UML, дозволяе просте $i$ зрозуміло схематичне порівняння різних організачійних структур з великою мірою гнучкості. Це дозволяє успішно зобразити еволюиію організаџійної структури. Структури, орієнтовані на користувача, та їх порівняння підкреслюють, що організаційна структура, особливо при наявності сис-темного інтегратора з точки зору користувачів, має сильний вплив на юзабіліті.

Ключові слова: методологія, організачійна структура, структура бізнесу, морський транспорт, юзабіліті. 
к.э.н., доцент кафедры «Предпринимательство и туризм» Одесский нацииональный морской университет, Одесса, Украина

\section{БИЗНЕС-СТРУКТУРЫ ДЛЯ ПРЕДПРИЯТИЯ МОРСКОГО ТРАНСПОРТА}

Аннотация. Исследования, представленные в этой статье, направлень на разработку методологии построения организационных структур предприятий морского транспорта и выявление организационных структур с помощью определенной методологии. Цель состоит в том, чтобы сделать схематическое сравнения различных организачионных структур морских транспортных услуг и проанализировать роль организационной структурь в связи с удобством использования морского транспорта. Учитыввая различные методологии бизнес-моделирования, методология, использованная в данной статье, базируется на UML (Unified Modeling Language), поскольку это мощуный аналитический метод для создания диаграмм из различных источников данных $и$ информации. Из данньх $u$ информации, собранной из литературы, как первая попытка, создаются общие диаграммы, позволяющие отразить эволючию бизнес-структурь морских транспортных организаций от одной из достаточно простых форм к другой, представляюшей типичное современное транспортное предприятие. Создано несколько диаграмм для представления различных сложных организационных структур транспорта с фокусом, установленным с точки зрения пользователей. Метод, основанный на UML, позволяет простое и понятно схематическое сравнения различных организационных структур с большой степенью гибкости. Это позволяет успешно изобразить эволючию организационной структуры. Структуры, ориентированные на пользователя, и их сравнение подчеркивают, что организационная структура, особенно наличие системного интегратора с точки зрения пользователей, имеет сильное влияние на юзабилити.

Ключевые слова: методология, организационная структура, структура бизнеса, морской транспорт, юзабилити.

\section{Problem}

statement. Organization and institutionalization are one of the most important aspects of maritime transport because of its laborintensive and mass-scale nature (Figure 1 and Figure 2). As seen in the next material, research has been carried out focusing on them, but few of them focused on the viewpoint of the users. Many of them focused on economic efficiency, relationships between authorities and operators, privatization and involvement of private financial resources, as well as rise of international transport operators.

The user's points of view are, however, important to evaluate easiness, usability and user-friendliness of maritime transport. A simple and easy transport service system can attract more of potential customers by offering better user experiences. This is especially important in the context of modal shift because transport is one of the sustainable transport modes. 
In addition, as the number of international relations tends to increase, simplicity is gaining more importance (Figure 3).

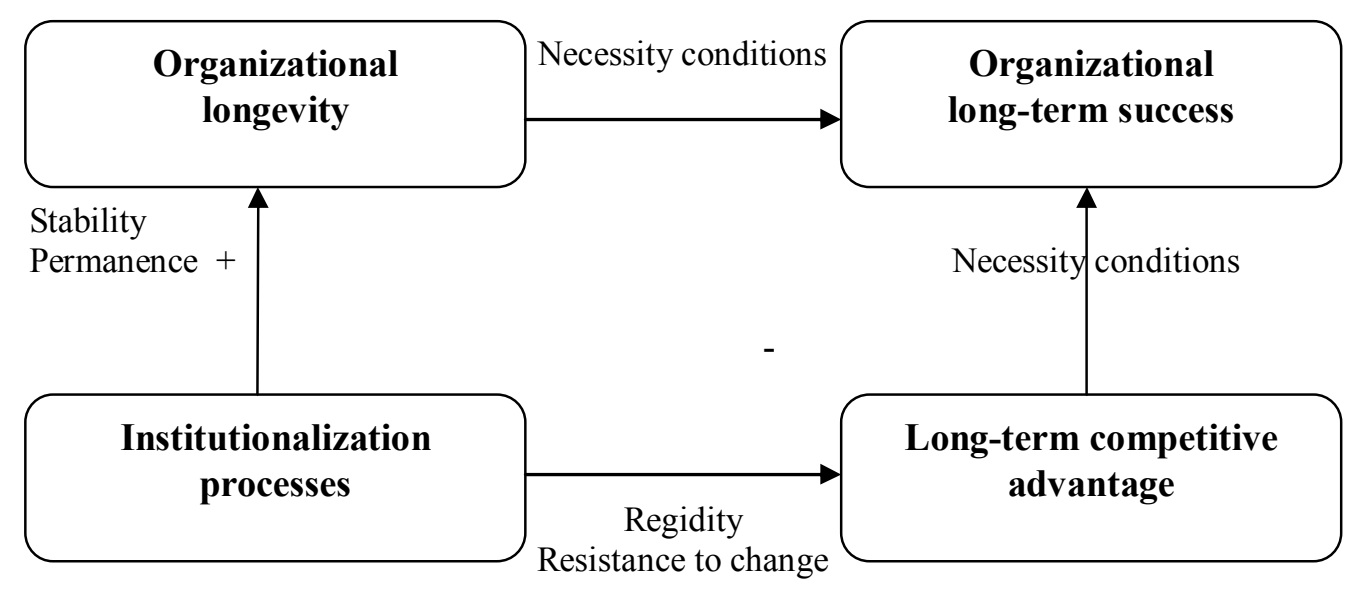

Figure 1. The Effect of Institutionalization Processes on Long-term Success

Designed by author

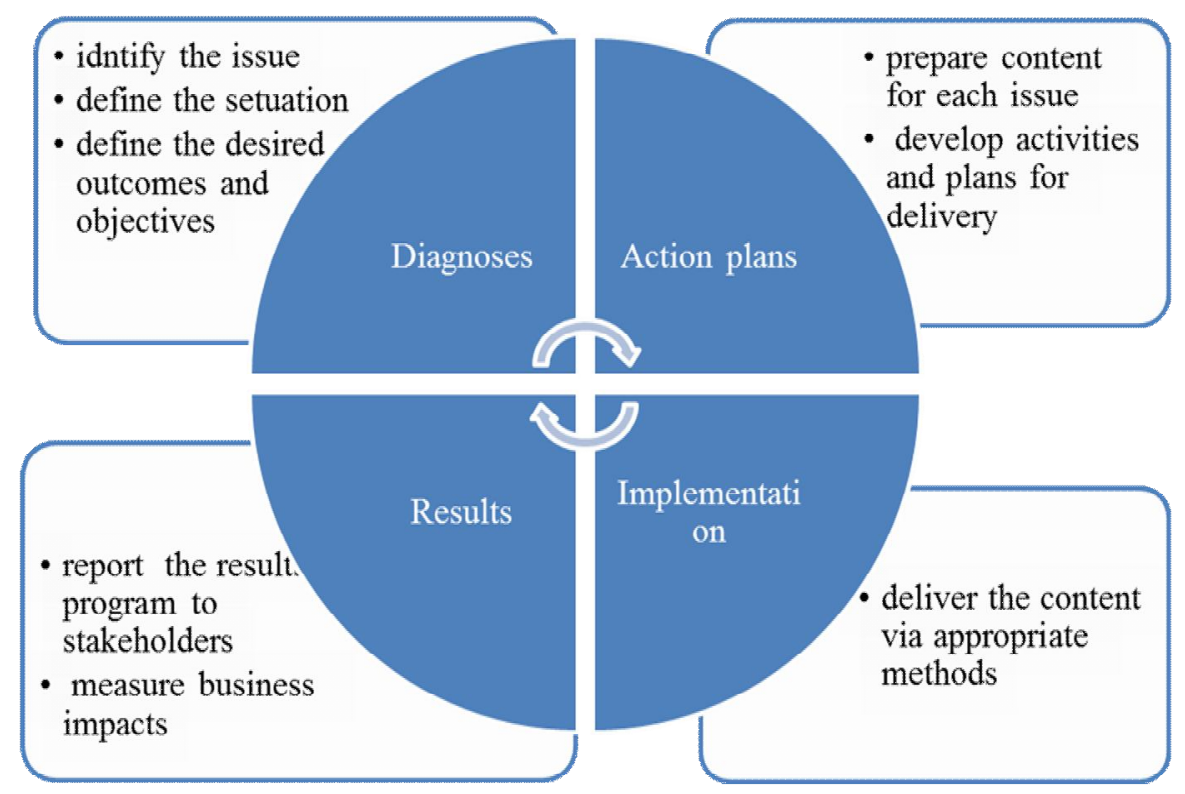

Figure 2. Organizational Development

Designed by author 


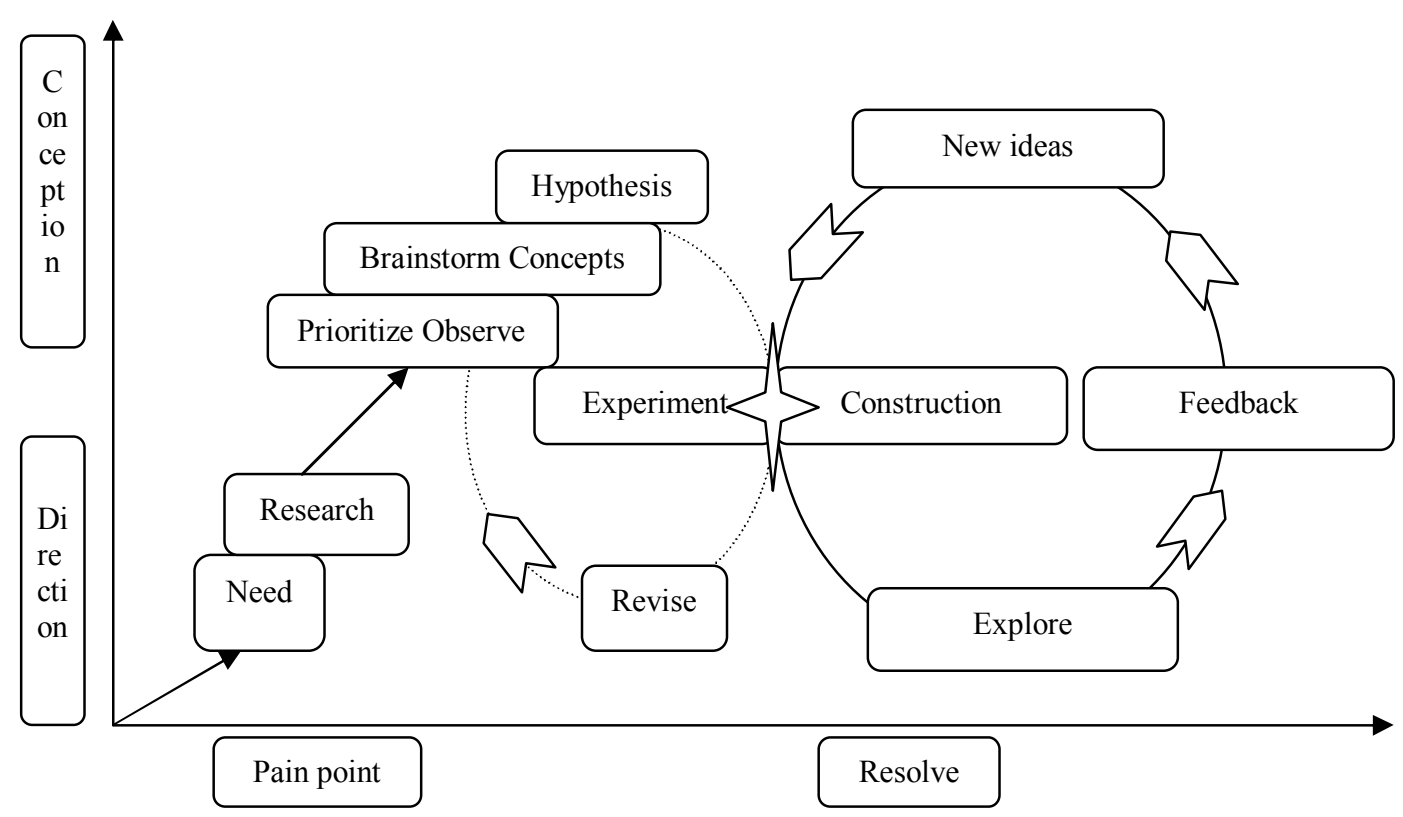

Figure 3. The drivers of effective structure building in the user's points of view

\section{Designed by author}

As the German, Swiss and Austrian has demonstrated $[2 ; 4 ; 8]$, to offer a better user experience, organization is one of the most important factor. However, methodology to identify and improve organizational structure from users' points of view has not yet been well established in a systematic manner. Description of the organizational structure has been relying on text, or at most on organizational diagrams. In the context of developing countries, integration of existing informal transit to more organized transport before extensive diffusions of intermodality is an important issue so that transport serves as a real modal choice to avoid unwanted problems such as downtime, extra costs and pollutions.
The aims of this paper are to develop a visual methodology of representation organizational structures in a complex, to apply this methodology to describe the evolution of organizational structures, to apply this methodology to compare the easiness of transport services from the viewpoint of the orga-nizational structure.

Review of the last research and publications. Restructuring the organizational structure of transport has been made repeatedly and it is documented often in a context of transport history [e.g. 1; 2]; but the focus is not set on the organization in this kind of literature. Recent changes and their impacts are summarized and analyzed in many of the literature $[2 ; 3 ; 4]$. Comparative approaches have been 
taken by many $[2 ; 8 ; 9]$, but some focuses on a single country $[2 ; 3 ; 8]$. A number of studies have been carried out onto operators' efficiency in relation to the organizational structures. Many of them have focused on operational or economic efficiency [2; 4].

While the aforementioned literature stands more on the points of view of the authority and operator, several literature deal the issues around the organizational structures more from the viewpoints of the users [3].

Various methodologies for business modeling have been developed, and many of them have advantages and disadvantages. To present organizational structures, certain methods have strengths to model complex structures of an organization embedded within it, while easiness to understand the diagram is often compensated. Some of the methodologies have been used for long time, while many of the latest methodologies originate in operations research, computerization of business process, and management research. Dynamic and Static models Haga [10] presents a good overview of business modeling that is related to computerization of business process.

Organigramm (Organizational chart) is a visual representation of the structure of an organization with organizational unit and relationships represented in the diagram [e.g. 11]. The organigramm has relatively long tradition compared to the other methods of business modeling. It appears to come from the need of the company to visualize the organizational structure. The characte-ristics of the organigram are that it represents the static structure of an organization, and it does not tell about the dynamic business process, as well as other information represented by time, money, each entity represented in the organigram is typically an organizational unit, but some important indivi-dual in the organization is often represented by his or her position as one entity, hierarchy, relationships and lines of authorities among each organizational unit are represented with line, but some organigram does not explicitly represent such relationship, and its syntax is easy to understand [e.g. 12]. Thus, in the construction of business structures, there are a number of tools, each of which has its advantages and disadvantages.

Tasks of research. The aim of the work is to analyze existing tools of building the maritime enterprise business structures and choose the most effective of them.

The basic material of research. The management of maritime transport enterprise expects the fulfillment of organization function. This process does not end at the stage of enterprise creation. For the viability of the marine transport company, it is necessary to change in line with changes in the environment constantly. This also applies to the business structure, which is the main form of existence of the enterprise.

Some of the tools to the building maritime enterprise business structures are organigram Vuchic and van de Velde [9] both constructed a very similar concept with three different levels, which inherit the concept of organigram such as presenting hierarchy and relationship. This presentation is abstract and generalized. According to them, transport has to incorporate the three levels: «strategic», «tactic» and «operational» levels. Strategic level 
refers to the high-level and often includes political decision-makings on long-term transport policy. According to van de Velde, this includes setting up targets such as profitability, and area coverage and connection with other transport modes (intermodality). Tactical level refers to the mid-term planning asso-ciated with the service. Operational level refers to the sales activities, produc- tion activities such as infrastructure management, vehicle rotation and maintenance as well as personnel rotation and maintenance. The concept is summarized in Figure 4.

\begin{tabular}{|c|c|c|c|c|}
\hline \multirow{3}{*}{$\begin{array}{l}\text { Decision } \\
\text { levels }\end{array}$} & \multicolumn{3}{|c|}{ By Van de Velde } & \multirow{3}{*}{ By Vuchic } \\
\hline & \multirow{2}{*}{$\begin{array}{c}\text { General } \\
\text { description }\end{array}$} & \multicolumn{2}{|c|}{ Decisions } & \\
\hline & & software & hardware & \\
\hline $\begin{array}{l}\text { Strategic } \\
\text { Level }\end{array}$ & $\begin{array}{c}\text { What do we } \\
\text { want to } \\
\text { achieve? } \\
\text { Long period (5 } \\
\text { years) }\end{array}$ & \multicolumn{2}{|c|}{$\begin{array}{c}\frac{\text { General aims }}{\text { Police }} \\
\text { Market } \\
\text { Profitability } \\
\text { General Service } \\
\text { Characteristics } \\
\text { Area } \\
\text { Target groups } \\
\text { Intermodality }\end{array}$} & $\begin{array}{l}\text { Implement policies } \\
\text { to integrate door- } \\
\text { to-door services }\end{array}$ \\
\hline \multirow[b]{2}{*}{ Tactic Level } & \multirow{2}{*}{$\begin{array}{l}\text { Which services } \\
\text { can help to } \\
\text { achieve these } \\
\text { aims? } \\
\text { Medium period } \\
\text { (1-2 years) }\end{array}$} & \multicolumn{2}{|c|}{$\begin{array}{c}\text { Detailed } \\
\text { service characteristics } \\
\end{array}$} & \multirow{2}{*}{$\begin{array}{l}\text { Plan networks } \\
\text { using optimal } \\
\text { modes and } \\
\text { technology }\end{array}$} \\
\hline & & $\begin{array}{c}\text { Fares } \\
\text { Image } \\
\text { Additional } \\
\text { Services }\end{array}$ & $\begin{array}{l}\text { Vehicles } \\
\text { Routes } \\
\text { Timetable } \\
\end{array}$ & \\
\hline $\begin{array}{l}\text { Operational } \\
\text { Level }\end{array}$ & $\begin{array}{l}\text { How to produce } \\
\text { these services? } \\
\text { Short period } \\
\text { (1-6 months) }\end{array}$ & $\begin{array}{l}\text { Sales } \\
\text { Selling } \\
\text { activities } \\
\text { Information } \\
\text { to the target } \\
\text { groups }\end{array}$ & $\frac{\text { Production }}{\text { Infrastructure }}$ & $\begin{array}{l}\text { Organize efficient } \\
\text { services by one } \\
\text { or more providers }\end{array}$ \\
\hline
\end{tabular}

Figure 4. Three layers in organizaiton of transport by Vuchic and van de Velde

\section{Designed by author}

Flowchart is a classical method of visualization any sort of process in a flow. One of the typical applications is to visualize the process that is carried out in software, but application to the business process is widely sought. The characteristics of the flowchart are that:

- it can visualize the dynamic process, including conditional statements, temporal delay, and input and output; 
- it is used widely in the world, and the syntax is standardized nationally and internationally;

- but it cannot visualize the static structure of the organization.

Some charts can present different divisions of the organization so that a complex process that is difficult to be handled only with the classical flowchart can be depicted. But they cannot visualize the structure of the organization [11]. Some approaches are used to analyze the business typically with a perspective to develop management system. The approach is useful when the business is analyzed in a macroscopic way to design an information system (Fig. 5).

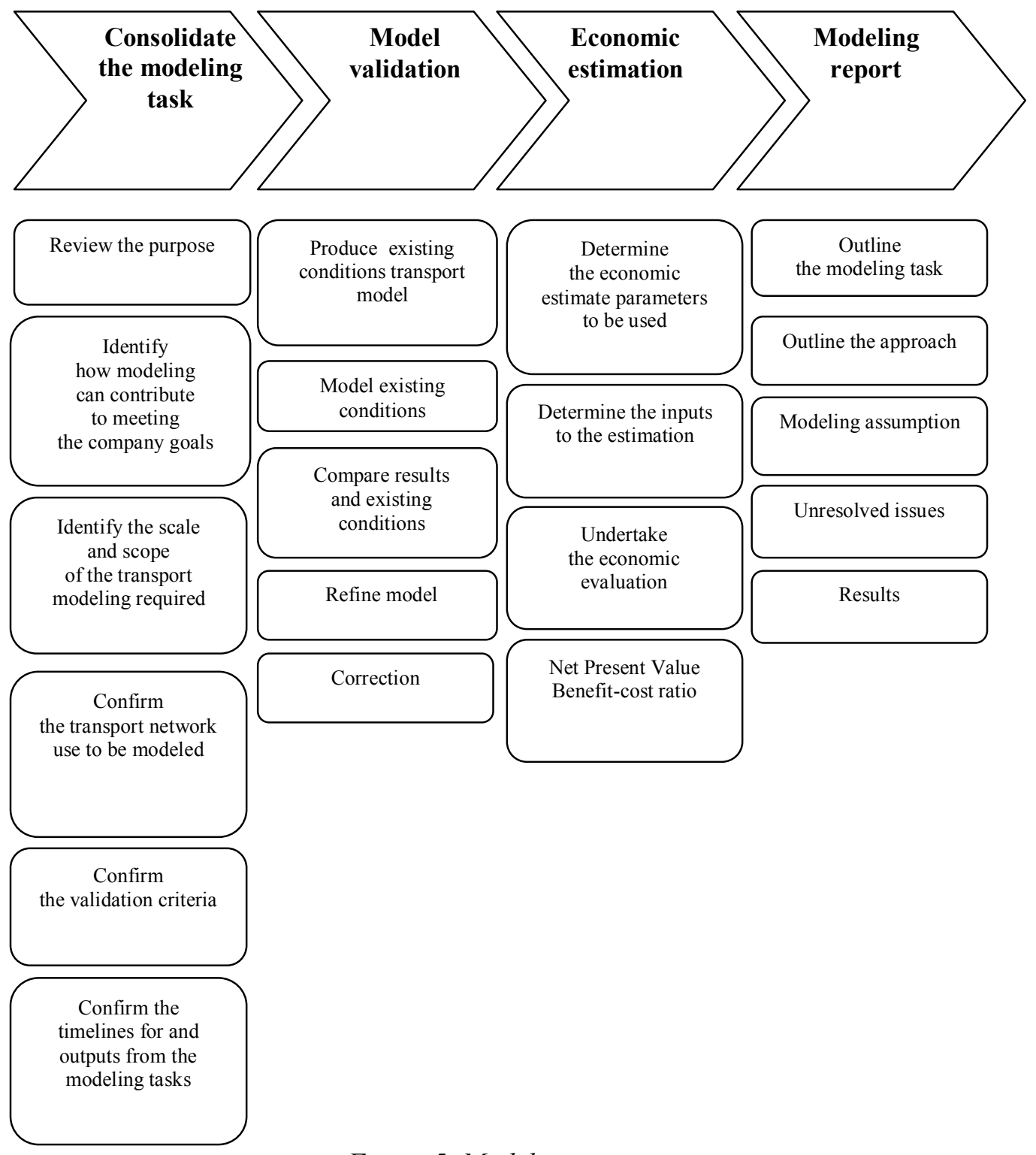

Figure 5. Modeling processes 


\section{Designed by author}

Integrated Definition methods were initially intended to be used in system engineering in the 1970s. Most relevant to business modeling is Function Modeling, Data Modeling, Process Description Capture and Object Oriented Design. The most useful for the organization modeling is IDEF0 Function Modeling because it enables the users to present "what is done» in the functional structure.

Some charts only allow visualizing the business process. Any sort of structure embedded in the business such as the functional structure of the institution cannot be visualized with these methods.

Unified Modeling Language is originally developed for object-oriented software engineering, while efforts have been made to apply it to the business modeling. UML consists of 14 diagrams, subdivided into seven structure diagrams and seven behavior diagrams. Most important and relevant diagrams have to be selected so that the aspects that are to be modeled are rationally depicted because it is time- and resourceconsuming. The most basic diagram presenting static structure is the class diagram, and the most basic one to depict dynamic pro-cess is activity diagram [13]. It applies to dynamic problems arising in complex social, managerial, economic, or ecological.

Class diagram is used to model the static relationship between various objects and thus this fulfills the requirements. The class diagram consists of several important elements: Class, Association, Generalization, Aggregation, Composition, and Package. Class is the most important element of the class diagram and shown by a rectangular. The basic version consists of three compartments (Figure 6 ): the one on the top is for the name of the class, the one in the middle is for properties, and the one on the bottom is for operations. The pro-perty compartment is used to describe variables or parameters.

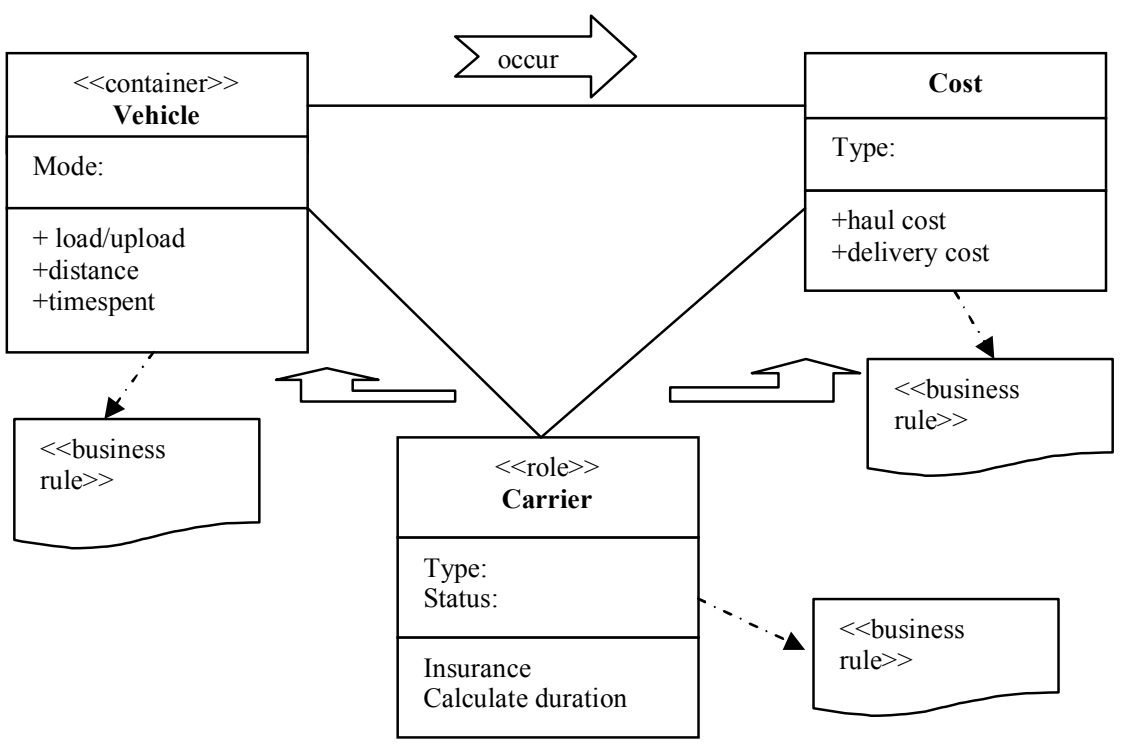


Figure 6. Class diagram for transport structures

Designed by author

The operation compartment is used to describe the actions that this class can carry out
The name compartment is mandatory, but the other compartments are optional (Fig. 7).

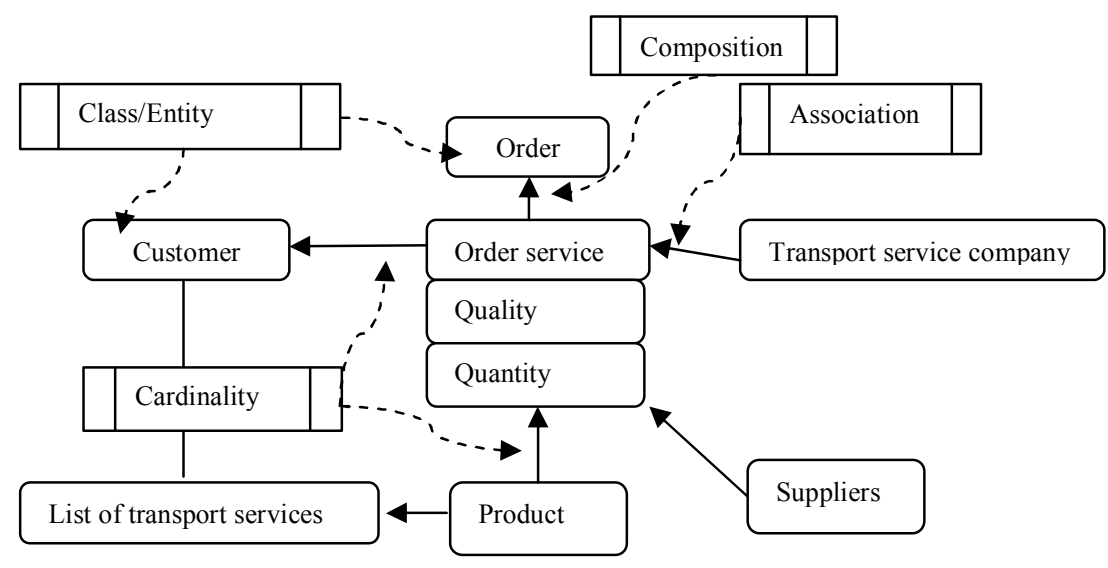

Figure 7. Technical Architecture Model

Designed by author

UML modeling can be using for different processes. UML offers a large extent of flexibility for modeling, but using just a few of the pre-defined UML's functions is enough to presenting the organizational structures of the maritime transport. The class diagram is more useful, and among its functions following ones:

- Class is used to depict the elements within the organizational structure. Such element can be a stakeholder, a service, or any other object that is needed for transport.

- These are connected by association. The multiplicity and the roles are written on the both ends of the line showing associations. $\begin{array}{ccc}\text { - } & \text { Where necessary, } \\ \text { generalization, aggregation and }\end{array}$ composition are used to show the partwhole relationships.

- Package is used to depict an organization / institution or a unit within an organization.

These demonstrates that the UML-based methodology is useful to present complex organizational structure of maritime transport based on various competences, products (services) and stakeholders embedded within it. Several potential use of this is identified through this process. First, comparison of similar but different organizational structure of maritime transport in a visualized manner is made possible. This is useful to understand 
characteristics, advantages and shortcomings embedded within organizational structures, as well as to gain a good overview. Second, this UML-based method can be used to identify potentials for improvements of the organizational structures and this will make it possible to identify possibilities for changes in the organizational structure. As this is a visualized method, this will also be a useful tool for communication among different stakeholders.

The user-oriented UML diagram shows that the service structure from users' points of view can be useful tool for management, communication, planning and rebuilding transport company on different stages of development. The UML-based methodology makes it possible to depict various organizational structure with a large extent of flexibi-lity. This means that various ways of depiction based on different focuses is made possible. This can serve also as a strong communication tool among various stakeholders. The evolution of the organizational structure depicted with this UML-based methodology demonstrates that an understanding of the development of organizational structure is made possible in a visualized manner. The UML-based method can also be applied to different occasions, such as integration. With users' viewpoints embedded in the diagrams, relationships between different levels of usability and different organizational structures, especially the existence of system integrators, are visually depicted. This metho-dology can be used to improve user experiences of marine transport through organizational approach.

Maritime transport is an important sector of economy and a link in the global, regional and local supply chains. Policy making is implemented under conditions of multiple objectives in an environment characterized by high complexity. The above creates the requirement of powerful and flexible decision support structures, able to cope with the challenge of the specific environment, the multiple and often non-monetised objectives and the incorporation of multiple stakeholders in the decision making process, in need of facilitating consensus building.

\section{REFERENCES}

1. Vuchic, V. (1999). Transportation for Livable Cities, Center for Urban Policy Research, New Brunswick.

2. Gagatsi E., Giannopoulos G., Aifantopoulou G., Charalampous G. (2016). Stakeholders-based multi-criteria policy analysis in maritime transport: from theory to practice, Greece.

3. Peng Peng, Yu Yang, Feng Lu, Shifen Cheng, Naixia Mou, Ren Yang. (2013). Modelling the competitiveness of the ports along the Maritime Silk Road with big data, International Journal of Production Economics, 2013.

4. Wayne K. Talley. (2014). Maritime transport chains: carrier, port and shipper choice effects, International Journal of Production Economics, 2014.

5. Kaiser W. (2008). Wiener Schienennahverkehr: Strassenbahn, Stadtbahn, U-Bahn, GeraMond Verlag, Munich. 
6. D. van de Velde. (1999). Organizational forms and entrepreneurship in public transport part 1: classifying organizational forms, Transport Policy 6 , 147-157.

7. Haga M. (2011). Object-oriented analysis for business modeling, Nikkan Kogyo Shimbun-sha, Tokyo.

8. Hellriegel J.W., Slocum D. (1989). Management, Addison-Wesley, 1989.

9. CHESS/NIATx University of Wisconsin-Madison, Swim lane (or crossfunctional) diagrams (n.d.). URL https://www.niatx.net/PDF/ PIToolbox/ swimlane.pdf

10. Noran O.S. (2000). Business modelling: Uml vs. idef.

11. Korthaus A. (1998). Using uml for business object based systems modeling, in: M. Schader, A. Korthaus (Eds.), The Unified Modeling Language, Physica-Verlag HD, book section 15, pp. 220-237. doi:10.1007/978-3-64248673-9 15. URL http://dx.doi.org/10.1007/978-3-642-48673-9 15

Article received 23.11.2018

Reference a JournalArtic: Matviienko M. (2018). Business structures at a maritime enterprise. Development of management and entrepreneurship methods on transport, 14-25. DOI: 10.31375/2226-1915-2018-4-14-25. 